\title{
Pengaruh Model Pembelajaran Numbered Heads Together Terhadap Mata Pelajaran Bahasa Indonesia Untuk Meningkatkan Hasil Belajar Siswa Tentang Menganalisis Teks Laporan Observasi di Kelas X MIPA
}

\author{
Mawarsih \\ SMAN 2 Bogor, Indonesia \\ email: mawarsih@gmail.com
}

\begin{abstract}
Abstrak
Penelitian ini bertujuan (1) untuk mengetahui model pembelajaran kooperatif tipe Number Heads Together (NHT) dapat meningkatkan hasil belajar peserta didik pada mata pelajaran Bahasa Indonesia tentang Teks Laporan Observasi pada Kelas X MIPA 6 SMA Negeri 2 Kota Bogor Semester Ganjil tahun pelajaran 2019/2020. (2) Untuk menggambarkan proses peningkatan hasil belajar peserta didik pada mata pelajaran Bahasa Indonesia tentang Teks Laporan Observasi pada Kelas X MIPA 6 SMA Negeri 2 Kota Bogor Semester Ganjil Tahun Pelajaran 2019/2020. 3) Untuk mengukur seberapa besar peningkatan hasil belajar peserta didik pada mata pelajaran bahasa Indonesia tentang Teks Laporan Observasi. Hasil penelitian menunjukkan bahwa model pembelajaran kooperatipe tipe Number Heads Together (NHT) terbukti dapat meningkatkan hasil belajar siswa nilai rata-rata sebelumnya dari 62,52 kemudian terjadi peningkatan setelah menggunakan model pembelajaran kooperatif tipe Number Heads Together (NHT) pada siklus1 rata-rata kelas 80,65 dan pada siklus 2 menjadi 87,21, dan siswa menjadi lebih bersemangat meningkatkan daya saing sehingga kelas terlihat aktif.
\end{abstract}

Kata kunci : Model Pembelajaran Numbered Heads Together; Hasil Belajar; Bahasa Indonesia

\begin{abstract}
This study aims (1) to find out the Number Heads Together (NHT) type cooperative learning model can improve student learning outcomes in Indonesian subjects regarding Observation Report Text in Class X MIPA 6 SMA Negeri 2 Bogor City Odd Semester 2019/2020 academic year . (2) To describe the process of improving student learning outcomes in Indonesian subjects regarding Observation Report Texts in Class X MIPA 6 SMA Negeri 2 Bogor City Odd Semester for the 2019/2020 Academic Year. 3) To measure how much increase in student learning outcomes in Indonesian subjects regarding Observation Report Text. The results showed that the Number Heads Together (NHT) cooperative learning model was proven to be able to improve student learning outcomes the previous average value of 62.52 then there was an increase after using the Number Heads Together (NHT) type cooperative learning model in the first cycle of the class average. 80.65 and in cycle 2 it becomes 87.21, and students become more enthusiastic in increasing competitiveness so that the class looks active.
\end{abstract}

Keywords: Numbered Heads Together Learning Model; Learning outcomes; Indonesian

\section{PENDAhUluan}

Pembelajaran Bahasa Indonesia sudah diajarkan semenjak sekolah tingkat dasar sampai perguruan tinggi dan ditunjang bahwa peserta didik menggunakan Bahasa Indonesia 
sebagai bahasa ibu. Dengan demikian pengajaran Bahasa Indonesia seharusnya sudah memiliki dasar untuk mencapai tujuan pembelajaran yaitu peserta didik dapat berbahasa Indonesia dengan baik dan benar. Materi pelajaran pun diambil dari kenyataan hidup sehari-hari yang dialami oleh semua peserta didik. Menilik dari hal itu peserta didik dipastikan dapat menerapkan kegiatan berbahasa dengan mudah karena peserta didik dalam pembelajaran hanya menstransfer apa yang dialami sehari-hari dalam kehidupan ke dalam pelajaran Bahasa Indonesia. Idealnya dengan kondisi seperti itu dapat dipastikan peserta didik tidak akan kesulitan dalam belajar maupun mengerjakan tes Bahasa Indonesia. Dalam kegiatan pembelajaran pun akan mudah diikuti dan dipahami karena disampaikan dan dibahas menggunakan bahasa yang dipakai sehari-hari. Namun banyak faktor yang terjadi di masyarakat ikut menentukan corak berbahasa peserta didik. Pergaulan sehari-hari peserta didik dalam berbagai situasi ikut memasukkan ragam berbahasa yang kompleks. Kebiasaan berbahasa yang hanya mengutamakan komunikatif dengan menghilangkan kaidah-kaidah berbahasa yang benar.

Di dalam masyarakat ditemukan bahwa asal lawan bicara mengerti dengan apa yang diucapkan, dianggap sudah cukup. Ditambah masuknya trend bahasa gaul di kalangan anak muda yang menabrak aturan resmi yang justru mendapat sambutan antusias dari kalangan muda. Hal itulah yang menyebabkan ketika peserta didik dihadapkan pada pelajaran Bahasa Indonesia di sekolah yang penuh dengan tatanan berbahasa yang baik dan benar mereka justru menjadi bingung dan tidak dapat mengetahui mana yang baku dan tidak sehingga mata pelajaran Bahasa Indonesia menjadi bahasa yang sulit. Untuk nilai Ujian Nasional pun banyak sekolah yang peserta didiknya mendapat nilai Bahasa Indonesia lebih rendah dari nilai bahasa asing (Bahasa Inggris). Faktor lain seperti materi pelajaran, metode atau model pembelajaran yang digunakan guru, sarana atau media pembelajaran yang digunakan dan lingkungan atau situasi kelas ikut pula berpengarauh dan saling berhubungan dalam menentukan hasil belajar peserta didik. Terkadang satu faktor saja yang kurang direncanakan atau diperhatikan akan dapat menyebabkan tujuan belajar akan gagal.

Dari yang peneliti amati dalam pengajaran yang dilaksanakan di SMA Negeri 2 Bogor khususnya kelas X, keanekaragaman model pembelajaran yang digunakan oleh guru Bahasa Indonesia masih kurang. Model pembelajaran yang diterapkan hanya sebatas peserta didik diberi tugas, mempresentasikan di depan kelas per kelompok, dan kelompok lainnya akan menanggapi sehingga terjadi proses tanya jawab, diskusi bahkan debat. Sebenarnya model ini sangat bagus karena melatih siswa untuk mencari bahan pelajaran, mendiskusikannya dan mempresentasikan. Tetapi apabila model ini dilakukan terus menerus atau monoton tanpa diselingi model pembelajaran yang lain lama kelamaan membuat peserta didik bosan. Imbasnya semangat belajar menjadi berkurang. Hal itulah yang menyebabkan nilai - nilai pada mata pelajaran Bahasa Indonesia tentang Teks Laporan Observasi tidak maksimal bahkan banyak yang tidak tuntas dari yang 
peneliti amati KKM yang sudah ditetapkan untuk kelas $\mathrm{X}$ adalah sebesar 70, di kelas $\mathrm{X}$ MIPA 6 ketika diberikan tes awal yang tuntas $18 \%$ atau 6 peserta didik yang mencapai ketuntasan dari 34 orang. Semangat belajar dan kondisi kelas pun menjadi kurang menyenangkan. Untuk itu peneliti mencoba memvariasikan model pembelajaran yang dipakai dengan menerapkan model pembelajaran Number Head Together (NHT)). Dalam pengajaran materi Teks Observasi, peneliti memilih model pembelajaran Number Head Together (NHT)) karena model ini memiliki keunggulan antara lain: (1) Melatih peserta didik bekerja mandiri, yaitu pada saat kuis sehingga mendorong peserta didik untuk menguasai materi dan tanggung jawab perorangan; (2) Melatih kerja sama dengan teman sehingga timbul rasa saling membantu dalam menguasai keterampilan yang diajarkan guru; (3) Mendorong kelompok peserta didik untuk melalakukan yang terbaik, memperhatikan norma-norma bahwa belajar itu penting, berharga dan menyenangkan; (4) Peserta didik menjadi terampil berdiskusi karena dalam langkah model pembelajaran NHT ini peserta didik bertukar jawaban, mendiskusikan ketidaksamaan, mencari pendekatan untuk memecahkan masalah; (5) Menimbulkan rasa saling menghargai karena mereka bisa saling memberikan pertanyaan tentang isi materi, mengajari teman sekelompok dan memperkirakan kelebihan dan kekurangan teman agar berhasil dalam tes.

\section{Metode Penelitian}

Metode Penelitian yang digunakan dalam penelitian ini adalah Penelitian Tindakan Kelas (PTK). Penelitan ini dilaksanakan di kelas X MIPA 6 SMA Negeri 2 Kota Bogor. Ketika guru mengajar Teks Laporan Observasi hasil nilai rata-rata dari 34 peserta didik hanya 6 peserta didik atau $18 \%$ yang memiliki nilai di atas KKM yang telah ditentukan dan 28 peserta didik atau 82\% memiliki nilai di bawah KKM, sedangkan KKM yang ditentukan adalah 70. Padahal materi Teks Laporan Observasi tentang ciri-ciri, pola penyajian, struktur, dan menyusun teks observasi bahasanya sangat mudah bagi peserta didik karena merupakan teks sederhana yang sering ditemukan dalam kehidupan sehari-hari termasuk oleh peserta didik tingkat SMA, jika kondisi tersebut tidak diatasi maka makna dan tujuan pembelajaran ini kurang tercapai. Penelitian ini dilaksanakan pada semester 1 tahun pelajaran 2019-2020, pada kelas X MIPA 6 materi teks Laporan Observasi tentang struktur teks dan ciri bahasa pada semester 1 antara bulan Juli s.d. Desember 2019. Adapun subyek penelitian ini adalah peserta didik kelas X MIPA 6 SMA Negeri 2 Kota Bogor berjumlah 34 peserta didik terdiri dari laki-laki 17 peserta didik dan perempuan 17 peserta didik.

Untuk mendapatkan data yang diperlukan oleh penulis digunakan instrumen pengumpulan data dengan (1) Tes Uji Kompetensi dan (2) Lembar Observasi. Rencana tindakan ini disusun untuk 2 (dua) siklus sesuai dengan perkiraan terpecahnya masalah ini secara optimal, yaitu 2 (dua) siklus. Siklus ke-1 menggunakan pendekatan kelompok 
dengan pembagian 8 kelompok. Masing-masing kelompok terdiri dari 4 orang. Siklus ke2 menggunakan pendekatan dengan pola tugas individual yaitu masing-masing peserta didik diberi tugas yang sama. Selanjutnya langkah-langkah setiap siklus terdiri dari: penetapan fokus masalah, perencanaan tindakan, pelaksanaan tindakan dan observasi, serta analisis dan refleksi. Untuk analisis tingkat keberhasilan atau persentase ketuntasan belajar peserta didik setelah proses belajar mengajar berlangsung pada tiap siklusnya, dilakukan dengan cara memberikan evaluasi berupa soal tes tertulis pada setiap akhir siklus. Analisis ini dihitung dengan menggunakan statistik sederhana berikut

1. Penilaian Evaluasi

Untuk menentukan nilai rata-rata peserta didik diperoleh dengan cara menjumlah nilai yang diperoleh peserta didik di kelas tersebut. Rumus sederhana yang digunakan untuk merata-rata nilai yaitu :

$$
\text { Nilai rata-rata }=\frac{\text { Jumlah semua nilai siswa }}{\text { Jumlah siswa }}
$$

2. Penilaian untuk Ketuntasan Belajar

Ditentukan dua kategori ketuntasan belajar yaitu secara perorangan dan secara klasikal.

Tabel 1. Ukuran Keberhasilan Penelitian

\begin{tabular}{|c|c|c|c|}
\hline No. & $\begin{array}{c}\text { Ukuran } \\
\text { Keberhasilan }\end{array}$ & Target & $\begin{array}{l}\text { Teknik Pengumpulan } \\
\text { Data }\end{array}$ \\
\hline 1 & $\begin{array}{l}\text { Ketuntasan belajar } \\
\text { perorangan }\end{array}$ & $\begin{array}{l}\text { Setiap peserta didik minimal } \\
\text { memperoleh nilai Kriteria } \\
\text { Ketuntasan Minimal (KKM ) } \\
70\end{array}$ & Hasil Tes \\
\hline 2 & $\begin{array}{l}\text { Ketuntasan } \\
\text { Klasikal }\end{array}$ & $\begin{array}{l}100 \% \text { peserta didik } \\
\text { memperoleh nilai mencapai } \\
\text { KKM }\end{array}$ & Hasil Tes \\
\hline 3 & $\begin{array}{l}\text { Semangat belajar } \\
\text { siswa }\end{array}$ & $\begin{array}{l}\text { Minimal 85\% peserta didik } \\
\text { menunjukkan semangat } \\
\text { belajar dan aktif dalam } \\
\text { pembelajaran }\end{array}$ & $\begin{array}{l}\text { Lembar Observasi } \\
\text { (pengamatan) }\end{array}$ \\
\hline
\end{tabular}

\section{Hasil dan Pembahasan}

Observasi awal di kelas yang akan diteliti merupakan tindakan dalam pendahuluan penelitian. Hasil observasi menunjukkan bahwa ketika guru mengajar teks observasi, hasil nilai rata-rata-rata memperoleh nilai 6,75. Dari 34 peserta didik hanya 6 atau 18\% 
yang memiliki nilai di atas KKM yang telah ditentukan dan 28 peserta didik atau 82\% memiliki nilai di bawah KKM. Padahal materi teks laporan hasil observasi tentang pola penyajian, struktur, penyusunan teks observasi bahasanya sederhana, maka diputuskanlah untuk model pembelajaran Number Head Together (NHT) pada mata pelajaran Bahasa Indonesia dalam teks observasi. Pembelajaran dimulai dengan mengadakan tes awal di kelas X MIPA 6 untuk mengetahui kemampuan awal peserta didik pada materi teks observasi. Nilai tes awal dijadikan acuan untuk mengetahui hasil belajar peserta didik kelas X MIPA 6 setelah model pembelajaran Number Head Together (NHT.) Soal-soal tes awal berupa materi yang berhubungan dengan materi yang akan diajarkan yaitu teks observasi. Perolehan nilai tes awal ini akan dijadikan acuan untuk mengetahui peningkatan hasil belajar peserta didik setelah menggunakan model pembelajaran Number Head Together (NHT). Berikut disajikan data hasil belajar peserta didik pada pra siklus sebagai berikut:

\section{Data Hasil Belajar Siswa Pra Siklus}

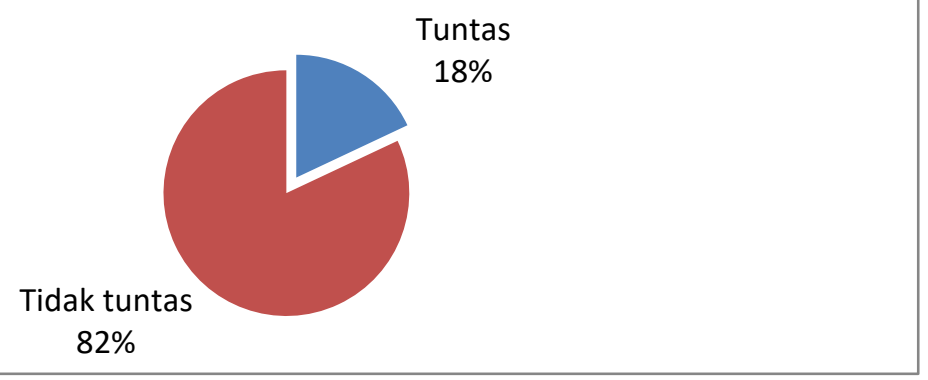

Gambar 1. Data Hasil Belajar Siswa Pada Pra Siklus

Berdasarkan gambar di atas terlihat bahwa peserta didik hanya memperoleh nilai ratarata dengan nilai tertinggi 85 dan nilai terendah 50 Peserta didik yang hasil belajarnya di atas KKM hanya 6 peserta didik atau 18\% dari nilai KKM yang ditetapkan yaitu 70. Hal ini memberikan gambaran bahwa hasil belajar peserta didik pada mata pelajaran Bahasa Indonesia masih tergolong rendah.

\section{Deskripsi Siklus I}

Dari hasil observasi siklus I, didapat bahwa dalam melaksanakan pembelajaran Bahasa Indonesia tentang struktur dan ciri bahasa teks observasi dengan menggunakan model pembelajaran Number Head Together (NHT) pada siklus I, guru telah menerapkannya sesuai dengan Rencana Pelaksanaan Pembelajaran (RPP) yang telah disiapkan. Berdasarkan hasil pengamatan yang dilakukan oleh observer, guru terlalu cepat dalam menjelaskan dan kurang banyak memberikan contoh dan tidak memaksimalkan penggunaan media pembelajaran. Masalah lain yang didapat dari pengamatan observer 
adalah pada saat guru menjelaskan materi, masih ada peserta didik yang kurang memperhatikan, juga beberapa peserta didik terlihat mengantuk.

Berdasarkan analisis data di atas, masih terdapat kekurangan pada siklus I. Kekurangan-kekurangan tersebut antara lain guru kurang mengamati proses belajar peserta didik dan guru kurang menggunakan media pembelajaran dalam proses pembelajaran. Sedangkan upaya memotivasi peserta didik, mengoptimalkan pelaksanaan model pembelajaran Number Head Together (NHT) , mengarahkan peserta didik untuk mengerjakan latihan belum optimal. Kemudian 12 (30\%) peserta didik belum fokus dalam memperhatikan pelajaran dan 5 (12,50\%) peserta didik tidak memperhatikan pelajaran. Dengan adanya kekurangan-kekurangan tersebut, maka perlu adanya perbaikan-perbaikan dalam KBM untuk siklus II.

\section{Deskripsi Siklus II}

Pada siklus II ini guru telah melakukan perbaikan-perbaikan. Perbaikan dalam KBM tersebut yaitu guru lebih memotivasi peserta didik, sehingga lebih bersemangat dalam mengikuti KBM. Dengan semangat yang lebih tinggi, maka pembelajaran dapat berjalan lebih baik. Selain memotivasi peserta didik, guru juga memberikan lebih banyak kesempatan kepada peserta didik untuk menanyakan hal-hal yang belum jelas. Data mengenai keaktifan peserta didik dapat diperoleh dengan menggunakan lembar observer seperti pada lampiran. Keaktifan peserta didik tersebut dapat dilihat dalam hal bertanya dan menjawab pertanyaan selama diskusi dan presentasi maupun antusiasnya dalam mengikuti pembelajaran. Data mengenai keaktifan peserta didik pada siklus II dapat dilihat pada gambar berikut:

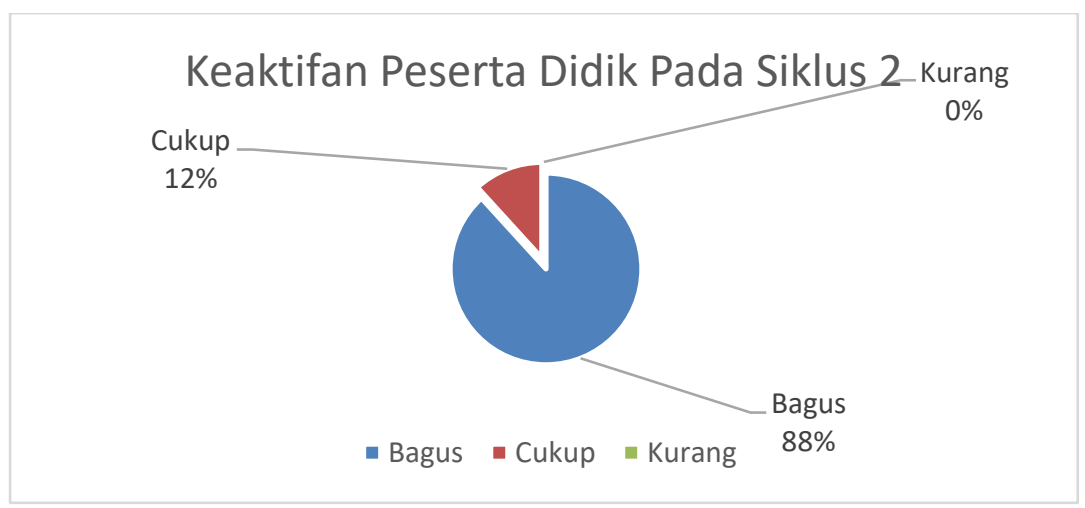

Gambar 2. Data Keaktifan Peserta Didik Pada Siklus 2

Dari gambar di atas mengenai aktifitas peserta didik pada siklus II menunjukkan 88,76\% atau 30 peserta didik termotivasi dalam mengikuti KBM, sedangkan 11,76\% atau 4 peserta didik cukup termotivasi dalam mengikuti KBM. Selanjutnya di bawah ini hasil 
pengamatan observer tentang aktivitas guru pada siklus II dapat dilihat pada gambar berikut:

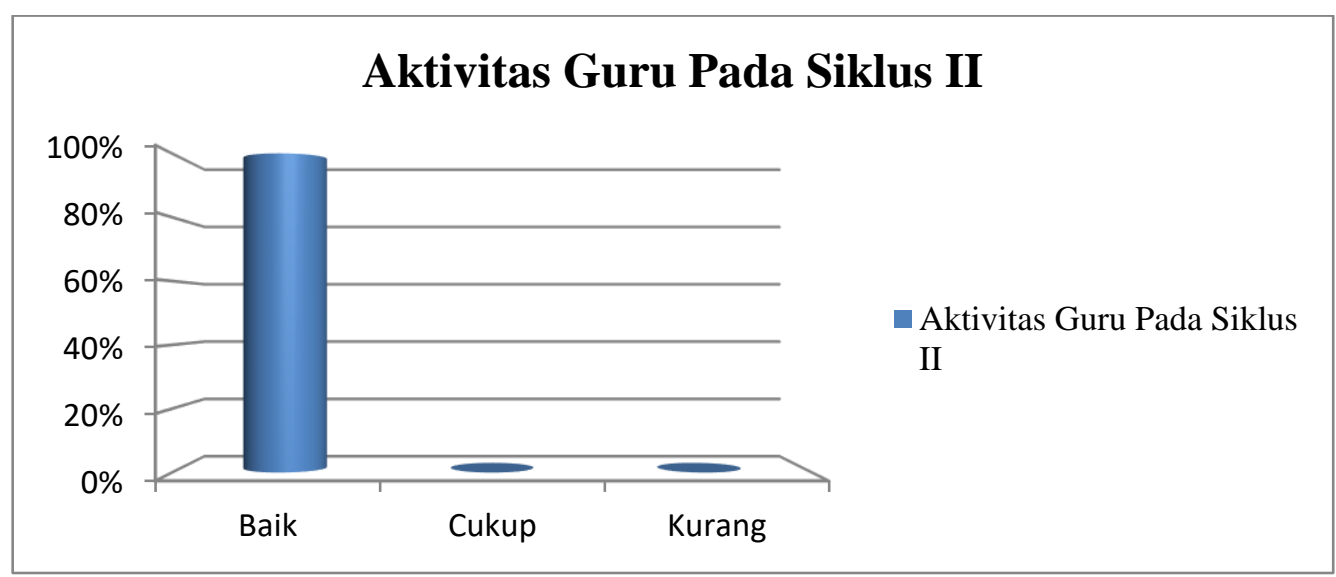

Gambar 3. Data Aktivitas Guru Pada Siklus 2

Untuk mengetahui besaran hasil belajar peserta didik, maka pada akhir siklus II dilakukan tes tertulis dengan hasil belajar dapat dilihat pada gambar berikut:

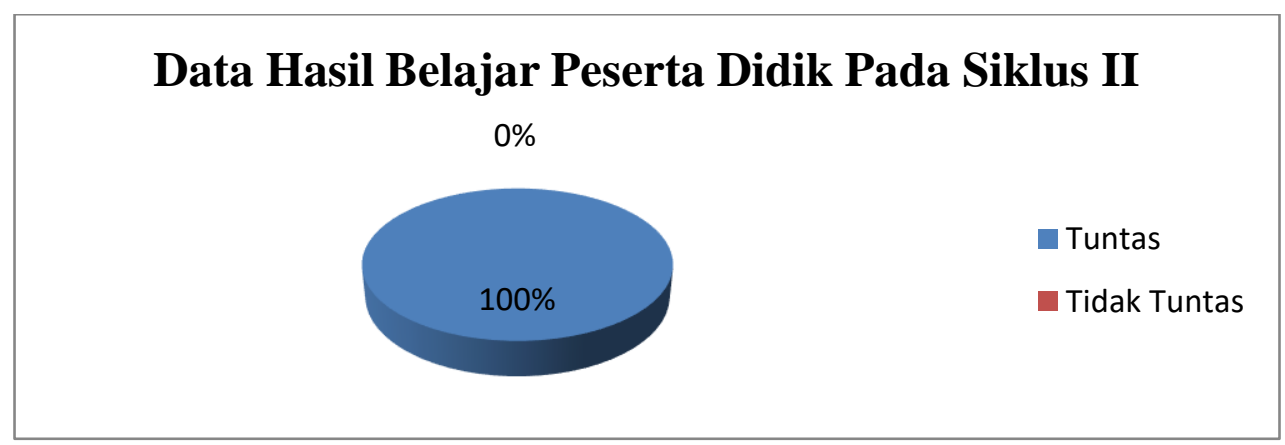

Gambar 4. Data Hasil Belajar Peserta Didik Pada Siklus 2

Berdasarkan gambar di atas terlihat bahwa rata-rata nilai peserta didik 87,21 dengan nilai tertinggi 95 dan nilai terendah 80. Peserta didik yang hasil belajarnya di atas KKM ada 34 orang atau $100 \%$ dan tidak ada peserta didik yang nilainya di bawah KKM yang ditetapkan yaitu 70. Hal ini memberikan gambaran bahwa ada peningkatan hasil belajar peserta didik dari siklus I ke siklus II.

Dari data di atas dapat diinformasikan bahwa seluruh peserta didik menyukai pembelajaran dengan model pembelajaran Number Head Together (NHT) dengan bukti rata-rata nilai 87,21 . Kemudian nilai di atas KKM ada 34 orang (100\%) sedangkan yang di bawah KKM tidak ada (0\%) dari KKM yang telah ditentukan yaitu 70. Nilai terendah adalah 80 dan nilai tertinggi 95. Seluruh peserta didik dalam materi teks observasi tentang ciri-ciri,struktur, dan penyusunan teks observasi sudah tuntas. Sedangkan aktivitas peserta didik dalam mengikuti materi ini sebanyak 91,18\% atau 31 dari 34 peserta didik sangat baik dalam mengikuti pelajaran. Hanya 8,82 \% atau 3 peserta didik yang kadang-kadang aktif. Kemudian aktivitas guru adalah 100\% guru mampu 
memotivasi dan mengarahkan peserta didik dalam materi ini. Hal ini dikarenakan peserta didik sangat antusias dan termotivasi dalam KBM yang menggunakan model pembelajaran Number Head Together (NHT).

Dari hasil pembelajaran menggunakan model pembelajaran Number Head Together (NHT) dan jawaban soal-soal evaluasi yang diberikan, kemudian peneliti menggunakan jawaban-jawaban tersebut untuk mengetahui apakah pembelajaran Bahasa Indonesia dengan model pembelajaran Number Head Together (NHT) tersebut dapat meningkatkan hasil belajar peserta didik kelas X MIPA 6 SMA Negeri 2 Kota Bogor semester 1 tahun pelajaran 2019-2020. Berikut ini adalah data hasil pra siklus, siklus pertama, dan siklus kedua yang terdapat dalam gambar berikut:

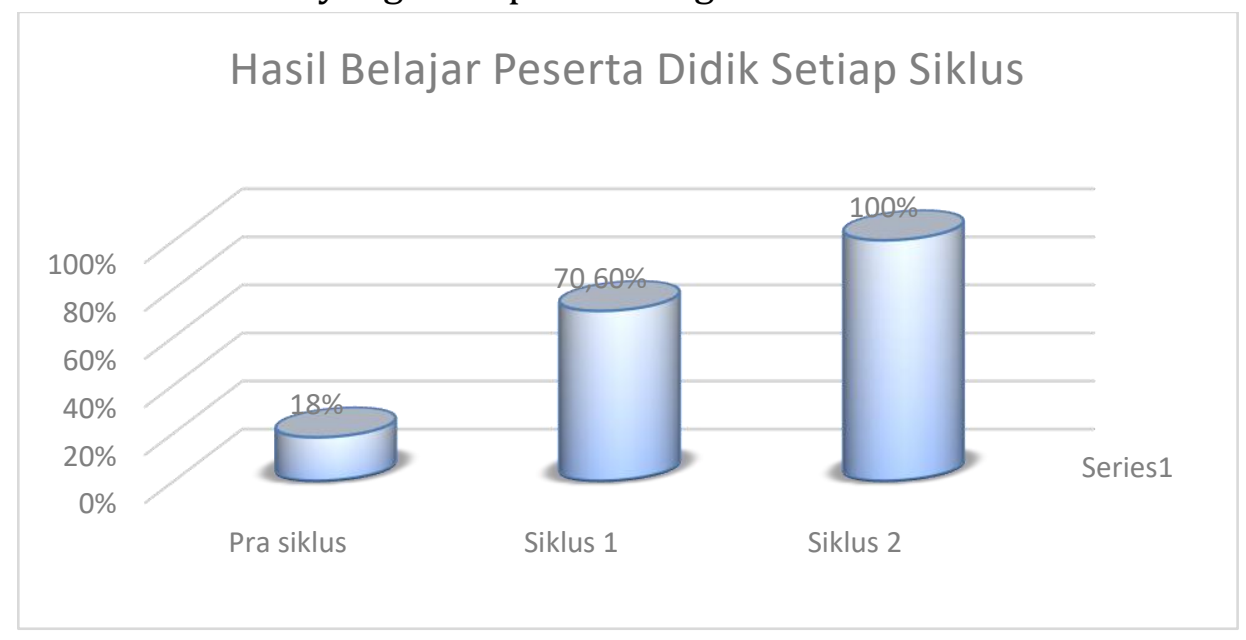

Gambar 5. Data Hasil Belajar Peserta Didik Pada Setiap Siklus

Peningkatan rata-rata nilai peserta didik juga ditunjang oleh peningkatan nilai terendah dan nilai tertinggi peserta didik setiap siklus seperti yang tergambar pada gambar berikut:

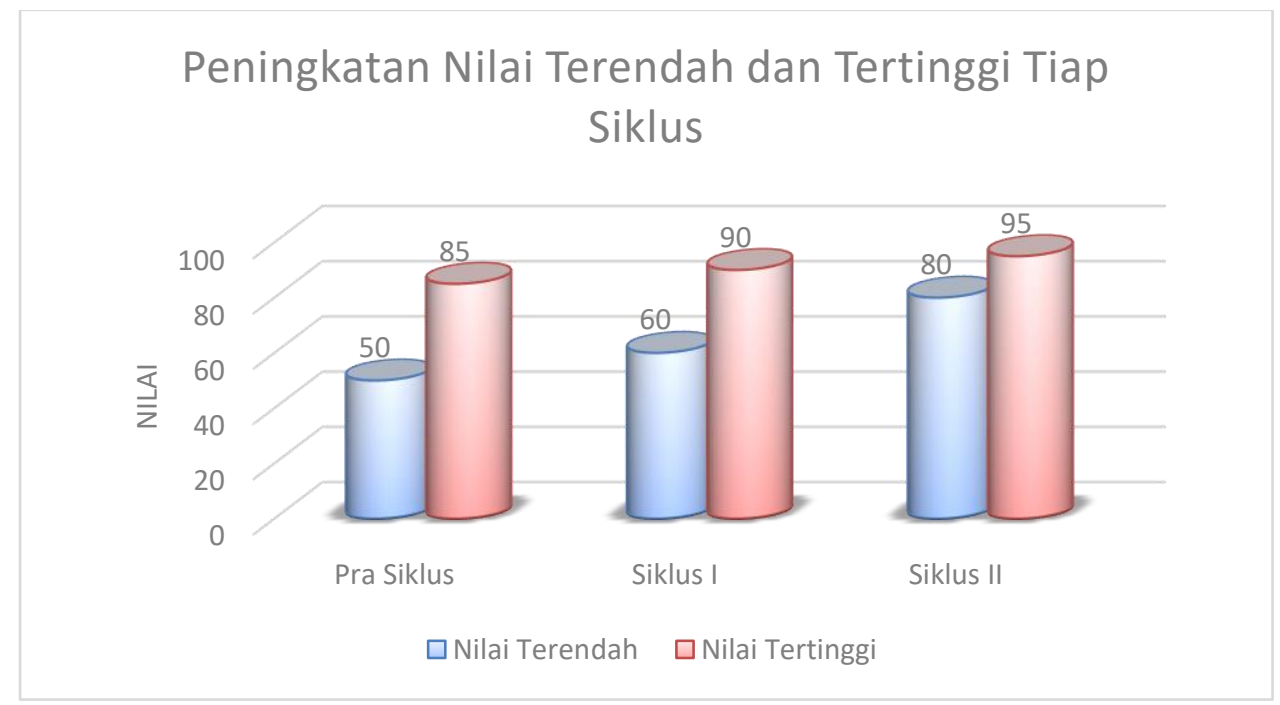

Gambar 6. Data Peningkatan Nilai Terendah dan Tertinggi Setiap Siklus 


\section{Mawarsih}

Dari gambar di atas diperoleh bahwa nilai terendah pada pra siklus adalah 50 kemudian meningkat menjadi 60 pada siklus I dan meningkat lagi menjadi 80 pada siklus II. Selanjutnya nilai tertinggi pada pra siklus adalah 85 kemudian meningkat menjadi 90 pada siklus I dan meningkat lagi menjadi 95 pada siklus II. Hal ini membuktikan bahwa model pembelajaran Number Head Together (NHT) cocok untuk diterapkan pada materi menganalisis teks observasi tentang struktur dan kebahasaannya.

\section{KESIMPULAN}

Kesimpulan dari hasil penelitian yang telah dilakukan tentang materi teks observasi bahwa hasil belajar peserta didik sesudah menggunakan model pembelajaran Number Head Together (NHT) menunjukkan hasil yang memuaskan. Dari uraian pada bab sebelumnya, dapat diambil simpulan sebagai berikut: (1) Adanya peningkatan hasil belajar peserta didik pada materi menganalisis teks observasi di kelas X MIPA 6 SMA Negeri 2 Kota Bogor Semester Ganjil tahun pelajaran 2019-2020 dengan model pembelajaran Number Head Together (NHT); (2) Penggunaan Model pembelajaran Number Head Together (NHT) dalam pembelajaran membuat peserta didik tidak bosan dan jenuh sebaliknya termotivasi untuk mengajukan pendapat sehingga aktivitas belajar mereka aktif dan menyenangkan yang mengakibatkan hasil belajar meningkat; (3) Hasil belajar mata pelajaran bahasa Indonesia materi teks observasi di kelas X MIPA 6 SMA Negeri 2 Kota Bogor Semester 1 tahun pelajaran 2015-2016 setelah menggunakan model pembelajaran Number Head Together (NHT) menjadi meningkat yang sebelum menggunakan model pembelajaran Number Head Together (NHT) mempunyai nilai rata-rata 62,52 menjadi 80.65 pada siklus I dan 87,21 pada siklus II; (4) Berdasarkan hasil penelitian selama dua siklus yang bertujuan untuk meningkatkan hasil belajar peserta didik pada materi tentang menganalisis teks observasi dilihat dari struktur teks dan ciri kebahasaan. Terlihat pada pelaksanaan siklus pertama dan kedua telah menunjukkan peningkatan. Hal ini membuktikan bahwa model pembelajaran Number Head Together (NHT) cocok untuk diterapkan pada materi menganalisis teks observasi.

\section{DAFTAR PUSTAKA}

Agam R. 2009. Menulis Karya Ilmiah, Panduan Lengkap Menulis Makalah, Skripsi, Tesis, Disertasi, dan Karya Ilmiah Populer. Yogyakarta (ID) : Familia Pustaka Keluarga.

Darmadi H. 2015. Desain dan Implementasi Penelitian Tindakan Kelas (PTK). Bandung (ID): Alfabeta.

Dimyati, Mujiono. 2011. Belajar dan Pembelajaran. Jakarta (ID) : Rineka Cipta. Jihad A, Haris A. 2012. Evaluasi Pembelajaran. Yogyakarta (ID): Multi Pressindo. Kementrian Pendidikan dan Kebudayaan RI. 2013. Buku Guru Bahasa Indonesia Eksposisi Diri dan Akademik. Jakarta (ID): Kemendikbud. 
Kementrian Pendidikan dan Kebudayaan RI. 2014. Buku Guru Bahasa Indonesia Eksposisi Diri dan Akademik Edisi Revisi. Jakarta (ID) : Kemendikbud.

Kementrian Pendidikan dan Kebudayaan RI. 2015. Materi Pelatihan Guru Implementasi Kurikulum 2013 Tahun 2015. Jakarta (ID) : Kemendikbud.

Permendikbud No. 34 Tahun 2014 tentang Pembelian Buku Kurikulum 2013 oleh Sekolah.

Permendikbud No. 59 Tahun 2014 tentang Kurikulum 2013 Sekolah Menengah Atas/Madrasah Aliyah.

Permendikbud No. 65 Tahun 2014 tentang Buku Teks Pelajaran dan Buku Panduan Guru

Kurikulum 2013 Kelompok Peminatan Pendidikan Menengah yang Memenuhi Syarat Kelayakan untuk Digunakan dalam Pembelajaran.

Rusman. 2013. Model-Model Pembelajaran Mengembangkan Profesionalisme Guru Edisi Kedua. Jakarta (ID): Rajawali Pers.

Trianto. 2012. Model-Model Pembelajaran Inovatif Berorientasi Konstruktivistik. Jakarta (ID). Prestasi Pustaka Publisher. 